\title{
Antitumor effects of ginsenoside Rg3 on human hepatocellular carcinoma cells
}

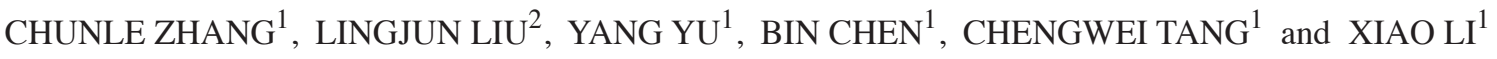 \\ Departments of ${ }^{1}$ Gastroenterology and Hepatology, and ${ }^{2}$ Radiology, West China Hospital, \\ Sichuan University, Chengdu, Sichuan, P.R. China
}

Received November 25, 2011; Accepted February 17, 2012

DOI: $10.3892 / \mathrm{mmr} .2012 .808$

\begin{abstract}
The antitumor effects of ginsenoside $\operatorname{Rg} 3$ have been reported in several kinds of human malignant tumors. The purpose of this study was to investigate whether ginsenoside $\mathrm{Rg} 3$ can inhibit the growth of human hepatocellular carcinoma cell lines and to discuss the possible molecular mechanism(s). We cultured the human hepatocellular carcinoma cell lines, SMMC-7721 and HepG2. The cells were treated with different concentrations of ginsenoside $\operatorname{Rg} 3(0,25,50,75$ and $100 \mu \mathrm{g} /$ $\mathrm{ml})$, and the cell proliferation was detected by MTT assay at the 12, 24, 36 and $48 \mathrm{~h}$ time-points. Flow cytometry experiments were carried out to investigate the effect of $\mathrm{Rg} 3$ on cell apoptosis after the cells had been treated with $\operatorname{Rg} 3(50$ and $100 \mu \mathrm{g} / \mathrm{ml})$ for 24 and $48 \mathrm{~h}$. The expression levels of caspase-3, bax and bcl-2 in $\mathrm{Rg} 3$-treated cells $(100 \mu \mathrm{g} / \mathrm{ml}, 48 \mathrm{~h}$ ), as well as normal cells were detected through real-time PCR experiments. MTT assay showed that the inhibition rate of cell proliferation in the $\mathrm{Rg} 3$ groups was significantly higher compared to the control groups in both the SMMC-7721 and HepG2 cell lines, and the inhibition rate increased with increasing $\operatorname{Rg} 3$ concentrations and duration of treatment. Flow cytometry analysis demonstrated that the $\mathrm{Rg} 3$ groups had a significantly higher cell apoptotic rate compared to the control groups in both the SMMC-7721 and HepG2 cell lines, and that the effect of Rg3 on cell apoptosis occurred in a concentration- and time-dependent manner, as was also shown by the MTT assay. Real-time PCR analysis showed that the gene expression levels of caspase-3 and bax were significantly enhanced in the $\mathrm{Rg} 3$ groups compared to the control groups in both the SMMC-7721 and HepG2 cell lines, but the gene expression level of $b c l-2$ was significantly inhibited. These results indicate that ginsenoside $\mathrm{Rg} 3$ can effectively inhibit the growth of human hepatocellular carcinoma cell lines by inhibiting cancer cell proliferation and promoting cancer cell apoptosis,
\end{abstract}

Correspondence to: Professor Xiao Li, Department of Gastroenterology and Hepatology, West China Hospital, Sichuan University, No. 37 Guoxue Lane, Chengdu, Sichuan 610041, P.R. China

E-mail: simonlixiao@263.net

Key words: ginsenoside $\operatorname{Rg} 3$, human hepatocellular carcinoma, SMMC-7721, HepG2, proliferation, apoptosis and it may promote cancer cell apoptosis via the endogenous mitochondrial-mediated caspase-dependent apoptotic pathway.

\section{Introduction}

One of the most serious complications of chronic liver disease is hepatocellular carcinoma. Worldwide, it is the 4th most common cancer and the 3rd most common cause of mortality from all cancers. Although a global cancer, it is especially prevalent in the Asia Pacific and sub-Saharan Africa (1). Chemotherapy is one of the most extensively investigated methods in anticancer therapies, but its efficacy and safety remain a primary concern, as the toxicity and other side-effects of chemotherapy are severe. In recent years, the search for anticancer drugs has leaned towards natural products; one of the most common natural drugs is ginsenoside $\operatorname{Rg} 3$ (2).

Ginsenoside $\operatorname{Rg} 3$ is an effective chemical trace component extracted from ginseng. The molecular formula of ginsenoside $\mathrm{Rg} 3$ is $\mathrm{C}_{42} \mathrm{H}_{72} \mathrm{O}_{13}$ and its molecular weight is 784.30 Da (3). Studies have found that ginsenoside Rg3 may have antitumor effects in several kinds of cancers, but its role in human hepatocellular carcinoma and the molecular mechanisms involved are not yet well comprehended. In this study, we cultured the human hepatocellular carcinoma cell lines, SMMC-7721 and HepG2, and investigated the effects of Rg3 on cell proliferation and apoptosis. We also studied the possible mechanisms involved by evaluating the expression profiles of apoptotic-related genes.

\section{Materials and methods}

Cell culture. The human hepatocellular carcinoma cell lines, SMMC-7721 and HepG2 (ATCC; Manassas, VA, USA), were cultured in Dulbecco's modified Eagle's medium (DMEM) supplemented with $10 \%$ fetal bovine serum plus ampicillin and streptomycin routinely, and incubated in $5 \% \mathrm{CO}_{2}$ at $37^{\circ} \mathrm{C}$.

MTT assay. MTT assay was performed to examine the cell proliferation. Cells in logarithmic phase were collected, an amount of $5 \times 10^{3}$ cells was seeded into 96-well plates with $100 \mu \mathrm{l}$ medium, and the plates were incubated at $37^{\circ} \mathrm{C}$ in a humidified incubator, $5 \% \mathrm{CO}_{2}$ for $24 \mathrm{~h}$. The medium was then removed and $100 \mu \mathrm{l}$ medium with different concentrations of $\mathrm{Rg} 3$ were added to each well. A control group and four $\operatorname{Rg} 3$ groups were set up, 
Table I. PCR primers.

\begin{tabular}{llc}
\hline Gene & \multicolumn{1}{c}{$\begin{array}{c}\text { Primer sequence } \\
\left(5^{\prime}-3^{\prime}\right)\end{array}$} & $\begin{array}{c}\text { Product size } \\
(\mathrm{bp})\end{array}$ \\
\hline caspase-3 & $\begin{array}{l}\text { F: TGGTTCATCCAGTCGCTTTG } \\
\text { R: ATTCTGTTGCCACCTTCGG }\end{array}$ & 100 \\
bax & $\begin{array}{l}\text { F: TTTGCTTCAGGGTTTCATCC } \\
\text { R: GAGTCTGTGTCCACGGCG }\end{array}$ & 186 \\
bcl-2 & $\begin{array}{l}\text { F: CCCGTTGCTTTCCTCTG } \\
\text { R: ATCTCCCGCATCCCACTC }\end{array}$ & \multirow{2}{*}{126} \\
GAPDH & F: GGAAGGTGAAGGTCGGAGT & \multirow{2}{*}{117} \\
& R: TGAGGTCAATGAAGGGGTC & \\
\hline
\end{tabular}

F, forward; R, reverse.

and the final concentration of $\mathrm{Rg} 3$ in each group was $0,25,50$, 75 and $100 \mu \mathrm{g} / \mathrm{ml}$, respectively. Each group had six replicates. A total amount of $20 \mu \mathrm{l}$ MTT reagent (Sigma, USA) was added to each well at the 12, 24, 36 and $48 \mathrm{~h}$ time-points. After culturing the cells for $4 \mathrm{~h}$ and removing the medium, $150 \mu \mathrm{l}$ of DMSO were added into each well, and the cells were incubated for $15 \mathrm{~min}$. Finally, the plates were read at the absorbance of a 490-nm wave length by a microplate reader (Model 680; Bio-Rad, Hercules, CA, USA). The experiment was repeated three times.

Flow cytometry. The effects of $\operatorname{Rg} 3$ on cell apoptosis were studied by flow cytometry (BD FACSAria II Cell Sorter, BD Company, Franklin Lakes, NJ USA). Cells in logarithmic phase were collected, an amount of $2 \times 10^{5}$ cells was seeded into 6-well plates with $2 \mathrm{ml}$ medium, and the plates were incubated at $37^{\circ} \mathrm{C}$ in a humidified incubator, $5 \% \mathrm{CO}_{2}$ for $24 \mathrm{~h}$. The medium was then removed and $2 \mathrm{ml}$ medium with different concentrations of $\operatorname{Rg} 3$ were added to the plates. A control and two $\operatorname{Rg} 3$ groups were set up, and the final concentration of $\operatorname{Rg} 3$ in each group was 0,50 and $100 \mu \mathrm{g} / \mathrm{ml}$, respectively. Each group had three triplicates. After 24 and $48 \mathrm{~h}$, the cells were collected, washed twice with PBS (2000 rmp, $5 \mathrm{~min}, 4^{\circ} \mathrm{C}$ ) and then the cells were resuspended in $400 \mu \mathrm{l}$ PBS. After the addition of $5 \mu \mathrm{l}$ Annexin V-FITC, the plates were gently agitated, and then the cells were incubated for $10 \mathrm{~min}$ at room temperature. This was followed by the addition of $10 \mu \mathrm{l} \mathrm{PI}(20 \mu \mathrm{g} / \mathrm{ml})$, and a further incubation for $30 \mathrm{~min}$ at $4^{\circ} \mathrm{C}$. Cell apoptosis was then evaluated by flow cytometry. The experiment was repeated three times.
Real-time PCR. Real-time PCR analysis was carried out to detect the expression levels of caspase-3, bax and bcl-2 in the SMMC-7721 and HepG2 cell lines. Cells were incubated as those in the flow cytometry experiment, the medium was removed after $24 \mathrm{~h}$, and $2 \mathrm{ml}$ medium with or without $\operatorname{Rg} 3$ were added to the plates. Two groups were set up as follows: the control (with no $\mathrm{Rg} 3$ ) and the Rg3 (with $100 \mu \mathrm{g} / \mathrm{ml} \mathrm{Rg} 3$ ). After being incubated for $48 \mathrm{~h}$, total RNA of each group was isolated using TRIzol RNA isolation reagent (Invitrogen, Carlsbad, CA, USA) according to the manufacturer's instructions. An amount of $1 \mu \mathrm{g}$ total RNA was reverse-transcribed into cDNA using the M-MuLV reverse transcriptase kit (Fermentas, Burlington, ON, Canada).

Real-time PCR was performed using SYBR Premix Ex Taq (Takara Bio, Shiga, Japan) according to the manufacturer's instructions. A total amount of $2 \mu \mathrm{l}$ cDNA template was used for each PCR reaction. The amplification was performed on the Bio-Rad C1000 real-time thermal cycler (Bio-Rad). The GAPDH gene was used as the endogenous control. PCR primers of caspase-3, bax, bcl-2 and GAPDH (control) are shown in Table I.

Statistical analysis. All values are presented as the means \pm standard error of the mean (SEM). Statistical analysis was performed using the Student's t-test with SPSS17.0. P $<0.05$ was considered to indicate a statistically significant difference.

\section{Results}

Cell proliferation. To detect the effects of $\mathrm{Rg} 3$ on cell proliferation, we carried out an MTT experiment in the SMMC-7721 and HepG2 cell lines. After the cells had been incubated for $12 \mathrm{~h}$, the cell proliferation of the $\mathrm{Rg} 3$ group showed a significantly increased inhibition rate when compared to the control group at each detected time-point (Tables II and III). In addition, the cell proliferation inhibition rate significantly increased in both the SMMC-7721 and HepG2 cells as the $\mathrm{Rg} 3$ concentration and treatment duration increased. This result suggests that $\operatorname{Rg} 3$ inhibits cancer cell proliferation in a concentration- and time-dependent manner (Fig. 1).

Cell apoptosis. To examine the role of $\mathrm{Rg} 3$ in cell apoptosis, we performed flow cytometry in SMMC-7721 and HepG2 cells. After these two types of cells been incubated for 24 and $48 \mathrm{~h}$, the cell apoptotic rate of the Rg3 group was significantly higher than that of the control, and the group of $100 \mu \mathrm{g} / \mathrm{ml}$ showed a significantly increased apoptotic rate when compared to the group of $50 \mu \mathrm{g} / \mathrm{ml}$. Furthermore, the apoptotic rate in the group

Table II. Effects of $\operatorname{Rg} 3$ on cell proliferation in SMMC-7721 cells $\left(\mathrm{A}_{490}\right)$.

\begin{tabular}{lccccc}
\hline Time-points (h) & \multicolumn{5}{c}{$\operatorname{Rg} 3(\mu \mathrm{g} / \mathrm{ml})$} \\
\cline { 2 - 6 } & 0 & 25 & 50 & 75 & 100 \\
\hline 12 & $0.497 \pm 0.016$ & $0.469 \pm 0.024^{\mathrm{a}}$ & $0.432 \pm 0.220^{\mathrm{a}}$ & $0.385 \pm 0.029^{\mathrm{a}}$ & $0.295 \pm 0.015^{\mathrm{a}}$ \\
24 & $0.622 \pm 0.027$ & $0.573 \pm 0.015^{\mathrm{a}}$ & $0.512 \pm 0.024^{\mathrm{a}}$ & $0.425 \pm 0.017^{\mathrm{a}}$ & $0.308 \pm 0.018^{\mathrm{a}}$ \\
36 & $0.765 \pm 0.028$ & $0.694 \pm 0.014^{\mathrm{a}}$ & $0.587 \pm 0.021^{\mathrm{a}}$ & $0.459 \pm 0.030^{\mathrm{a}}$ & $0.316 \pm 0.022^{\mathrm{a}}$ \\
48 & $0.912 \pm 0.027$ & $0.799 \pm 0.025^{\mathrm{a}}$ & $0.585 \pm 0.019^{\mathrm{a}}$ & $0.437 \pm 0.020^{\mathrm{a}}$ & $0.321 \pm 0.020^{\mathrm{a}}$ \\
\hline
\end{tabular}

All values represent the means $\pm \mathrm{SD}$. ${ }^{a} \mathrm{P}<0.05$ indicates statistically significant differences vs. the control group. 
Table III. Effects of $\mathrm{Rg} 3$ on cell proliferation in HepG2 cells $\left(\mathrm{A}_{490}\right)$.

\begin{tabular}{|c|c|c|c|c|c|}
\hline \multirow[t]{2}{*}{ Time-points (h) } & \multicolumn{5}{|c|}{$\operatorname{Rg} 3(\mu \mathrm{g} / \mathrm{ml})$} \\
\hline & 0 & 25 & 50 & 75 & 100 \\
\hline 12 & $0.456 \pm 0.016$ & $0.428 \pm 0.016^{\mathrm{a}}$ & $0.384 \pm 0.210^{\mathrm{a}}$ & $0.336 \pm 0.011^{\mathrm{a}}$ & $0.289 \pm 0.017^{\mathrm{a}}$ \\
\hline 24 & $0.609 \pm 0.029$ & $0.554 \pm 0.019^{\mathrm{a}}$ & $0.488 \pm 0.024^{\mathrm{a}}$ & $0.421 \pm 0.025^{\mathrm{a}}$ & $0.336 \pm 0.018^{\mathrm{a}}$ \\
\hline 36 & $0.753 \pm 0.029$ & $0.654 \pm 0.017^{\mathrm{a}}$ & $0.569 \pm 0.020^{\mathrm{a}}$ & $0.466 \pm 0.015^{\mathrm{a}}$ & $0.352 \pm 0.018^{\mathrm{a}}$ \\
\hline 48 & $0.908 \pm 0.036$ & $0.769 \pm 0.025^{\mathrm{a}}$ & $0.623 \pm 0.023^{\mathrm{a}}$ & $0.457 \pm 0.017^{\mathrm{a}}$ & $0.368 \pm 0.021^{\mathrm{a}}$ \\
\hline
\end{tabular}

All values represent the means $\pm \mathrm{SD} .{ }^{\mathrm{a}} \mathrm{P}<0.05$ indicates statistically significant differences vs. the control group.

Table IV. Effects of $\operatorname{Rg} 3$ on cell apoptosis (\%).

\begin{tabular}{|c|c|c|c|c|c|c|}
\hline \multirow[t]{2}{*}{ Time-points (h) } & \multicolumn{3}{|c|}{ SMMC-7721 $(\mu \mathrm{g} / \mathrm{ml})$} & \multicolumn{3}{|c|}{ HepG2 $(\mu \mathrm{g} / \mathrm{ml})$} \\
\hline & 0 & 50 & 100 & 0 & 50 & 100 \\
\hline 24 & $10.370 \pm 2.27$ & $22.33 \pm 3.37^{\mathrm{a}}$ & $37.93 \pm 3.37^{\mathrm{a}}$ & $11.67 \pm 2.23$ & $29.3 \pm 1.68^{\mathrm{a}}$ & $36.90 \pm 2.00^{\mathrm{a}}$ \\
\hline 48 & $15.737 \pm 1.66$ & $37.67 \pm 1.88^{\mathrm{ab}}$ & $46.90 \pm 1.45^{\mathrm{ab}}$ & $17.03 \pm 1.05$ & $41.5 \pm 1.76^{\mathrm{ab}}$ & $50.83 \pm 3.21^{\mathrm{ab}}$ \\
\hline
\end{tabular}

All values represent the means $\pm \mathrm{SD}$. ${ }^{\mathrm{a}} \mathrm{P}<0.05$ indicates statistically significant differences vs. the control group; ${ }^{\text {b }} \mathrm{P}<0.05$ indicates statistically significant differences vs. the 24-h group.

A

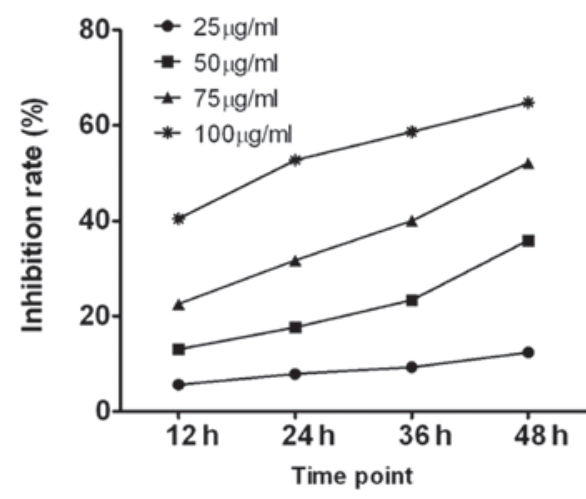

B

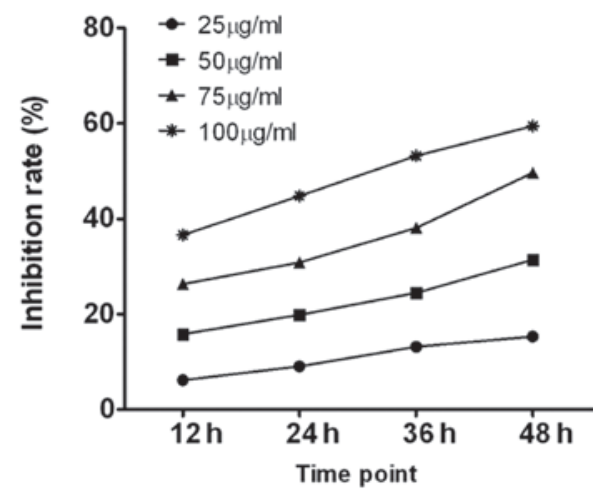

Figure 1. Cell proliferation inhibition rate. (A) SMMC-7721 cell line. (B) HepG2 cell line.

A

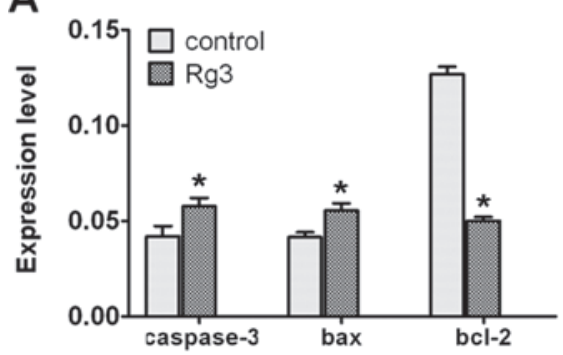

B

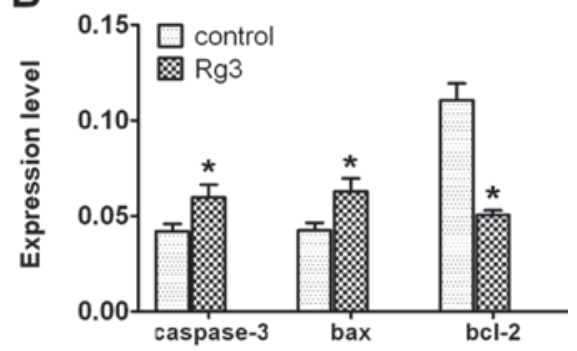

Figure 2. Expression levels of caspase-3, bax and bcl-2. (A) SMMC-7721 cell line. (B) HepG2 cell line. All values represent the means \pm SD. ${ }^{*}<0.05$ denotes statistically significant differences vs. the control group.

of $48 \mathrm{~h}$ was higher than the group of $24 \mathrm{~h}$ (Table IV). This results was statistically significant and showed that $\mathrm{Rg} 3$ promoted cancer cell apoptosis in a concentration- and time-dependent manner which was consistent with the results of the MTT assay. 
Expression levels of caspase-3, bax and bcl-2. In an effort to determine the effects of $\mathrm{Rg} 3$ on the expression profile of apoptotic-related genes, we used real-time PCR technology to detect the mRNA expression levels of caspase-3, bax and bcl-2 genes in the Rg3 and control groups. Real-time PCR analysis demonstrated that the expression levels of caspase- 3 and bax were upregulated in the $\mathrm{Rg} 3$ groups when compared to the control group in both the SMMC-7721 and HepG2 cell lines, but the expression level of $b c l-2$ was downregulated in the $\mathrm{Rg} 3$ group when compared to the control (Fig. 2).

\section{Discussion}

Ginseng is one of the most commonly used Chinese medicines in China, Asia and Western countries. The beneficial effects of ginseng have been attributed to the biological activities of its constituents, the ginsenosides (4). To date, more than 150 naturally occurring ginsenosides have been isolated from roots, leaves, stems, fruits and flower heads of ginseng. It has been reported that the potential health effects of ginsenosides include anticarcinogenic, immunomodulatory, anti-inflammatory, anti-allergic, antiatherosclerotic, antihypertensive, antidiabetic and antistress activities and effects on the central nervous system (5). Amongst all ginsenosides isolated from ginseng, ginsenoside $\mathrm{Rg} 3$ has gained much attention for its antitumor properties (6). Studies have found that $\operatorname{Rg} 3$ has significant anticarcinogenic effects in several kinds of malignant tumors, such as melanoma (7), colon $(8-10)$, ovarian $(11,12)$, prostate (13), breast (14) and lung cancer $(15,16)$, but its role in human hepatocellular carcinoma is not yet well comprehended.

In the present study, we investigated the role of $\mathrm{Rg} 3$ in the human hepatocellular carcinoma cell lines, SMMC-7721 and HepG2, by detecting cell proliferation and apoptosis. The results demonstrate that $\mathrm{Rg} 3$ inhibits cancer cell proliferation and promotes cancer cell apoptosis in a concentration- and time-dependent manner. We speculate that $\operatorname{Rg} 3$ may have antitumor effects in human hepatocellular carcinoma by inhibiting cancer cell growth. This result is consistent with previous studies on the anticarcinogenic effects $\operatorname{Rg} 3$ in other malignant tumors (7-16).

In order to study the molecular mechanism of $\mathrm{Rg} 3$ in human hepatocellular carcinoma, we carried out real-time PCR analysis to detect the expression levels of apoptotic-related genes before and after liver cancer cells being were treated with $\mathrm{Rg} 3$. Our results showed that $\operatorname{Rg} 3$ upregulated caspase-3 expression. Caspase- 3 is a final executive molecule in the caspase-dependent apoptotic signal transduction pathway. This suggests that $\mathrm{Rg} 3$ may significantly promote liver cancer cell apoptosis through the caspase-dependent pathway. Furthermore, we found that $\mathrm{Rg} 3$ may upregulate $b a x$ and downregulate $b c l-2$ expressions. $B a x$ is a pro-apoptotic gene and $b c l-2$ is an anti-apoptotic gene from the $b c l-2$ family. $B c l-2$ family is an important regulator in the endogenous mitochondrial apoptotic pathway, which can determine whether the mitochondria stimulate cell apoptosis and release pro-apoptotic factors, such as cytochrome c $(17,18)$. This indicates that Rg3 may promote liver cancer cell apoptosis in an endogenous mitochondrial apoptotic pathway through a caspase-dependent mechanism.

In summary, our study shows that ginsenoside Rg3 inhibits the growth of human hepatocellular carcinoma cells, possibly via the endogenous mitochondrial-mediated caspase-dependent apoptotic pathway, thus laying the foundation for further studies on $\operatorname{Rg} 3$ in human liver cancer. Nonetheless, its role in animal experiments and clinical trials still requires further investigation.

\section{Acknowledgements}

This study was supported by The National Natural Science Foundation of China (Grant no. 81171444).

\section{References}

1. Lui HF: Screening for hepatocellular carcinoma. Int J Hepatol: 363151, 2011.

2. Tan W, Lu J, Chen M, et al: Anti-cancer natural products isolated from Chinese medicinal herbs. Chin Med 6: 27, 2011.

3. Kitagawa I, Yoshikawa M, Yoshihara M, Hayashi $\mathrm{T}$ and Taniyama T: Chemical studies of crude drugs (1). Constituents of Ginseng radix rubra. Yakugaku Zasshi 103: 612-622, 1983 (In Japanese)

4. Lee DC and Lau AS: Effects of Panax ginseng on tumor necrosis factor- $\alpha$-mediated inflammation: a mini-review. Molecules 16: 2802-2816, 2011.

5. Christensen LP: Ginsenosides chemistry, biosynthesis, analysis, and potential health effects. Adv Food Nutr Res 55: 1-99, 2009.

6. Jia L, Zhao Y and Liang XJ: Current evaluation of the millennium phytomedicine-ginseng (II): Collected chemical entities, modern pharmacology, and clinical applications emanated from traditional Chinese medicine. Curr Med Chem 16: 2924-2942, 2009.

7. Chen J, Peng H, Ou-Yang X and He X: Research on the antitumor effect of ginsenoside Rg3 in B16 melanoma cells. Melanoma Res 18: 322-329, 2008.

8. Luo X, Wang CZ, Chen J, et al: Characterization of gene expression regulated by American ginseng and ginsenoside Rg3 in human colorectal cancer cells. Int J Oncol 32: 975-983, 2008.

9. Kim SM, Lee SY, Yuk DY, et al: Inhibition of NF-kB by ginsenoside $\mathrm{Rg} 3$ enhances the susceptibility of colon cancer cells to docetaxel. Arch Pharm Res 32: 755-765, 2009.

10. Lee SY, Kim GT, Roh SH, et al: Proteomic analysis of the anticancer effect of 20S-ginsenoside Rg3 in human colon cancer cell lines. Biosci Biotechnol Biochem 73: 811-816, 2009.

11. Xu TM, Cui MH, Xin Y, et al: Inhibitory effect of ginsenoside $\mathrm{Rg} 3$ on ovarian cancer metastasis. Chin Med J (Engl) 121: 1394-1397, 2008.

12. Xu TM, Xin Y, Cui MH, Jiang X and Gu LP: Inhibitory effect of ginsenoside $\mathrm{Rg} 3$ combined with cyclophosphamide on growth and angiogenesis of ovarian cancer. Chin Med J (Engl) 120: 584-588, 2007.

13. Kim HS, Lee EH, Ko SR, Choi KJ, Park JH and Im DS: Effects of ginsenosides $\mathrm{Rg} 3$ and $\mathrm{Rh} 2$ on the proliferation of prostate cancer cells. Arch Pharm Res 27: 429-435, 2004.

14. Zhang Q, Kang X, Yang B, Wang J and Yang F: Antiangiogenic effect of capecitabine combined with ginsenoside $\operatorname{Rg} 3$ on breast cancer in mice. Cancer Biother Radiopharm 23: 647-653, 2008.

15. Lu P, Su W, Miao ZH, Niu HR, Liu J and Hua QL: Effect and mechanism of ginsenoside $\mathrm{Rg} 3$ on postoperative life span of patients with non-small cell lung cancer. Chin J Integr Med 14: 33-36, 2008.

16. Liu TG, Huang Y, Cui DD, Huang XB, Mao SH, Ji LL, Song HB and Yi C: Inhibitory effect of ginsenoside $\mathrm{Rg} 3$ combined with gemcitabine on angiogenesis and growth of lung cancer in mice. BMC Cancer 9: 250, 2009.

17. Gustafsson AB and Gottlieb RA: Bcl-2 family members and apoptosis, taken to heart. Am J Physiol Cell Physiol 292: C45-C51, 2007.

18. Danial NN and Korsmeyer SJ: Cell death: critical control points. Cell 116: 205-219, 2004. 